\title{
EFFECT OF BREED AND FEEDING SYSTEM ON CONTENT OF SELECTED WHEY PROTEINS IN COW'S MILK IN SPRING-SUMMER AND AUTUMN-WINTER SEASONS
}

\author{
Aneta Brodziak ${ }^{1}$, Joanna Barłowska², Jolanta Król2, \\ Zygmunt Litwińczuk ${ }^{1}$ \\ 'Department of Breeding and Protection of Genetic Resources of Cattle, \\ ${ }^{2}$ Department of Commodity Science and Processing of Raw Animal Materials, \\ University of Life Sciences in Lublin, Akademicka 13, 20-950 Lublin, Poland \\ Corresponding author: aneta.brodziak@up.lublin.pl
}

\begin{abstract}
The objective of the present study was to evaluate the effect of breed and feeding system on the content of selected whey proteins in cow's milk collected in the spring-summer and autumn-winter periods. A total of $\mathbf{2 , 2 7 8}$ milk samples from Black- and Red-and-White variety of Polish Holstein-Friesian cows and Simmental and Jersey cows were examined. In each sample the content of selected whey proteins, i.e. alpha-LA, beta-LG, lactoferrin, BSA and lysozyme, was analysed by RP-HPLC method. Evaluation of the simultaneous effect of breed and production season on whey protein content showed significant interactions $(\mathrm{P} \leq \mathbf{0 . 0 5}$ and $\mathrm{P} \leq 0.01)$ for all analysed whey proteins. The milk of Simmental cows kept in the conventional system was characterized by a higher content of whey proteins (with the exception of BSA), in comparison to the cows managed under TMR system. Furthermore, for most of the evaluated components, except the content of BSA and lysozyme and the alpha-LA/beta-LG ratio, the simultaneous effect of feeding system and production season was also found.
\end{abstract}

Key words: whey proteins, cow breed, feeding system, production season

Milk proteins, which are an integral component of food, are considered the richest source of ingredients, both nutritional and functional. In terms of nutritional value, they are the reserve of energy and essential amino acids determining proper growth and development of the human organism. The main source of these proteins is whey, a by-product of cheese production in the dairy industry. In 2009 its production amounted to 1.1 million tons, including 160,000 tons of whey powder (IERiGŻ-PIB, 2010). Whey proteins have the ability to reduce the risk of many diseases of modern civilization (Konrad and Kleinschmidt, 2008; Król et al., 2010 a; Liu et al., 2007). They also contribute to binding and transport of macro-and microelements (Farrell et al., 2004; Indyk, 2009). It is generally accepted that changes in the content of milk components are caused in more than $50 \%$ by genetic factors and in about $40 \%$ by 
environmental ones (Krzyżewski et al., 1997). Walker et al. (2004) and Barłowska (2007) stated that seasonal changes in milk composition are mainly the result of diversified feeding in autumn-winter and spring-summer periods, but also they occurred due to variations in ambient temperature or animal keeping conditions.

The objective of the present study was to evaluate the effect of breed and feeding system on the content of selected whey proteins in cow's milk collected in the spring-summer and autumn-winter periods.

\section{Material and methods}

\section{Material}

The study was conducted throughout three successive years (2007-2009), in 17 farms keeping dairy cows of three major breeds in Poland, i.e. Black- and Redand-White variety of Polish Holstein-Friesian, Simmental and Jersey. These farms are located in eastern and south-eastern Poland. All Polish Holstein-Friesian and Jersey cows were managed under an intensive system in free-stall barns. Animal feeding system, established over both the spring-summer and autumn-winter season, was based on a Total Mixed Ration (TMR), i.e. $20 \mathrm{~kg}$ of maize silage, $15 \mathrm{~kg}$ of haylage, $4 \mathrm{~kg}$ balanced feed and $1 \mathrm{~kg}$ of protein concentrate. Moreover, in all farms the cows received a supplement of standard mineral-vitamin mixture for dairy cows (MMB), in the amount of 120-170 g, depending on yield and type of mixture. Simmental cows were divided into two study groups. One group of these cows, from the Lublin and Bieszczady region, was also managed in free-stall barns under an intensive feeding system (TMR system) and received about $25 \mathrm{~kg}$ of haylage, $4 \mathrm{~kg}$ of balanced feed and $1 \mathrm{~kg}$ of protein concentrate, and 120-170 $\mathrm{g}$ of standard mineral-vitamin mixture. However, the cows from the second group were maintained in tie-stall barns in the Bieszczady region and a conventional feeding system was only used. In the springsummer period animals grazed pasture ad libitum (about $50 \mathrm{~kg}$ of grasses daily), receiving $3 \mathrm{~kg}$ of hay and $2 \mathrm{~kg}$ of crushed cereal meal additionally. In the autumnwinter season animal feeding was based on haylage (about $30 \mathrm{~kg}$ ), $2 \mathrm{~kg}$ of hay and $2 \mathrm{~kg}$ crushed cereal meal. Therefore, two feeding systems, i.e. TMR and conventional, were distinguished for the Simmental breed in order to more precisely determine the effect of feeding system on the content of the analysed components of milk.

Milk samples were collected individually from each cow during test milking which took place twice a year, once in the autumn-winter (December-February) period and again in the spring-summer period (May-July). A total of 2,278 milk samples were examined (789 from Black-and-White variety of Polish Holstein-Friesian, 486 from Red-and-White variety of Polish Holstein-Friesian, 768 from Simmental and 235 from Jersey cows). From Simmental cows managed under the intensive system 395 samples of milk were obtained, i.e. 203 in the spring-summer season and 192 in the autumn-winter period, whereas 373 samples from the cows kept according to the conventional feeding system, i.e. 188 in the spring-summer season and 185 in the autumn-winter season. 


\section{Chemical analysis}

All milk samples collected into plastic containers were transported to the laboratory of the Department of Commodity Science and Processing of Animal Raw Materials at the University of Life Sciences in Lublin (Poland).

To evaluate the content of chosen whey proteins, i.e. alpha-lactalbumin (alphaLA), beta-lactoglobulin (beta-LG), lactoferrin, bovine serum albumin (BSA) and lysozyme, whey samples from milk of cows were prepared according to a modified version of the method described by Romero et al. (1996): $50 \mathrm{ml}$ of raw milk was adjusted to $\mathrm{pH} 4.6$ with $0.1 \mathrm{~mol} / \mathrm{dm}^{3} \mathrm{HCl}$ and allowed to stand at room temperature for acid precipitation of caseins. Consequently, whey (about $5 \mathrm{ml}$ ) was taken from each of the samples separately and then centrifuged. Finally, whey solutions were filtered through quality filters and then through $0.20-\mu \mathrm{m}$ disposable sterile filters (Millipore, type GSTF). The supernatants in vials were refrigerated until further analysis and, when appropriate, injected into the chromatograph (in the amount of $20 \mu \mathrm{l}$ ).

The separation of milk whey proteins was performed by RP-HPLC. The whole system consisted of HPLC apparatus, ProStar 210 pumping system, ProStar 410 autosampler and ProStar 325 UV-VIS detector (Varian, USA). The system was controlled by Varian Star Chromatography Workstation System ver. 6.2. The measurements were carried out using the water/acetonitrile mobile phase at gradient elution and NUCLEOSIL 300-5 C18 column (Varian, USA) of $250 \mathrm{~mm}$ length and $4.6 \mathrm{~mm}$ diameter. The mobile phase was solvent A (90\% water, 10\% acetonitrile) and solvent B (90\% acetonitrile, 10\% water) purchased from Sigma (Germany). All chemicals were HPLC analytical grade. The solvents were filtered through $0.45-\mu \mathrm{m}$ filters (Millipore, USA) and degassed. Total analysis time for a single sample was $35 \mathrm{~min}$ at $205 \mathrm{~nm}$ wavelength with column temperature of $37^{\circ} \mathrm{C}$.

\section{Calibration}

The analyses of reference substances were conducted under the same conditions. The calibration of the chromatographic system for whey proteins determination was carried out by the external standard method. For this purpose, each protein was calibrated individually by injection of the standard solutions $(20 \mu \mathrm{l})$. The standards were purified proteins, i.e. alpha-LA ( $\geq 85 \%)$, beta-LG $(90 \%)$, BSA $(\geq 96 \%)$ and lactoferrin $(90 \%)$ from bovine milk, as well lysozyme (95\%) from hen egg whites, which were purchased from Sigma (Germany). On the basis of the chromatograms obtained using the program Star 6.2 Chromatography Workstation (Varian, USA), the qualitative and quantitative identification of each substance was performed.

\section{Data analysis}

The statistical analysis included the effect of cow breed, production season and feeding system using the following linear model:

$$
Y_{i j k}=\mu+a_{i}+b_{j}+c_{k}+\left(a_{i} \times b_{j}\right)+\left(a_{i} \times c_{k}\right)+\left(b_{j} \times c_{k}\right)+e_{i j k}
$$

where:

$Y_{i j k}$-dependent variable,

$\mu$ - effect of total mean, 
$a_{i}$ - effect of cow breed $(\mathrm{i}=1 \ldots 4)$,

$b_{j}$ - effect of production season $(\mathrm{j}=1,2)$,

$c_{k}$ - effect of feeding system $(\mathrm{k}=1,2)$,

$\left(a_{i} \times b_{j}\right),\left(a_{i} \times c_{k}\right),\left(b_{j} \times c_{k}\right)-$ effect of interaction of two factors,

$e_{i j k}$-random error.

The results obtained were analysed by the factorial ANOVA procedures of Statistica ver.6 (Statsoft Inc. 2003). This was done based on one-way and multifactorial analysis of variance with interaction, using Tukey's HSD procedure.

\section{Results}

Results included in Table 1 indicate a significant influence of breed on the analysed whey protein content. Milk obtained from Polish Holstein-Friesian cows, the most important breed for milk production in both Poland and the world, contained the lowest amount of compounds evaluated. Interestingly, the richest source of these proteins was milk from Simmental cows. A significant $(\mathrm{P} \leq 0.01)$ influence of season on the whey protein content and alpha-LA/beta-LG ratio was also stated (Table 1). In the spring-summer season, regardless of the breed, cows produced milk with higher concentrations of the constituents evaluated. In the autumn-winter season, depending on the breed, milk contained from 0.01 to $0.09 \mathrm{~g} / \mathrm{dm}^{3}$ less alpha-LA, from 0.02 to $0.36 \mathrm{~g} / \mathrm{dm}^{3}$ less beta-LG, from 8.25 to $22.71 \mathrm{mg} / \mathrm{dm}^{3}$ less lactoferrin and from 0.49 to $1.30 \mu \mathrm{g} / \mathrm{dm}^{3}$ less lysozyme. It should be noted that the smallest differences between seasons were found in the milk of Polish Holstein-Friesian cows. Milk collected in the autumn-winter season was characterized by a higher content of BSA; however, significant differences $(\mathrm{P} \leq 0.01)$ of $0.03 \mathrm{~g} / \mathrm{dm}^{3}$ were reported for milk from Simmental and Jersey cows. On the basis of two-way analysis of variance, taking into account the breed and production season, significant interactions $(\mathrm{P} \leq 0.01)$ for betaLG, BSA, lactoferrin and alpha-LA/beta-LG ratio as well as at $\mathrm{P} \leq 0.05$ for alpha-LA and lysozyme were stated.

Using the example of the Simmental cows, for which it was possible to distinguish two systems of feeding, significant differences between the groups in the concentration of proteins reported were discussed (Table 2). The milk of Simmental cows maintained in the conventional system, both in the spring-summer and autumnwinter seasons, was characterized by a higher content of whey proteins, with the exception of BSA, particularly in the period when the animals were kept on a pasture. In comparison with the cows fed the TMR, this milk contained more alpha-LA (by $0.09 \mathrm{~g} / \mathrm{dm}^{3}$ ), beta-LG (by $0.09 \mathrm{~g} / \mathrm{dm}^{3}$ ), lactoferrin (by $16.81 \mathrm{mg} / \mathrm{dm}^{3}$ ) and lysozyme (by $0.65 \mu \mathrm{g} / \mathrm{dm}^{3}$ ). In the spring-summer season these differences were higher by $44 \%, 1.11$ times, $41 \%$ and $34 \%$, respectively. The highest content of BSA, however, was observed in the milk of cows fed using the TMR system $\left(0.48 \mathrm{~g} / \mathrm{dm}^{3}\right)$, especially in the autumn-winter period. When analysing a simultaneous effect of feeding system and production season, significant interactions $(\mathrm{P} \leq 0.01)$ for the content of alphaLA, beta-LG and lactoferrin were found (Table 2). 


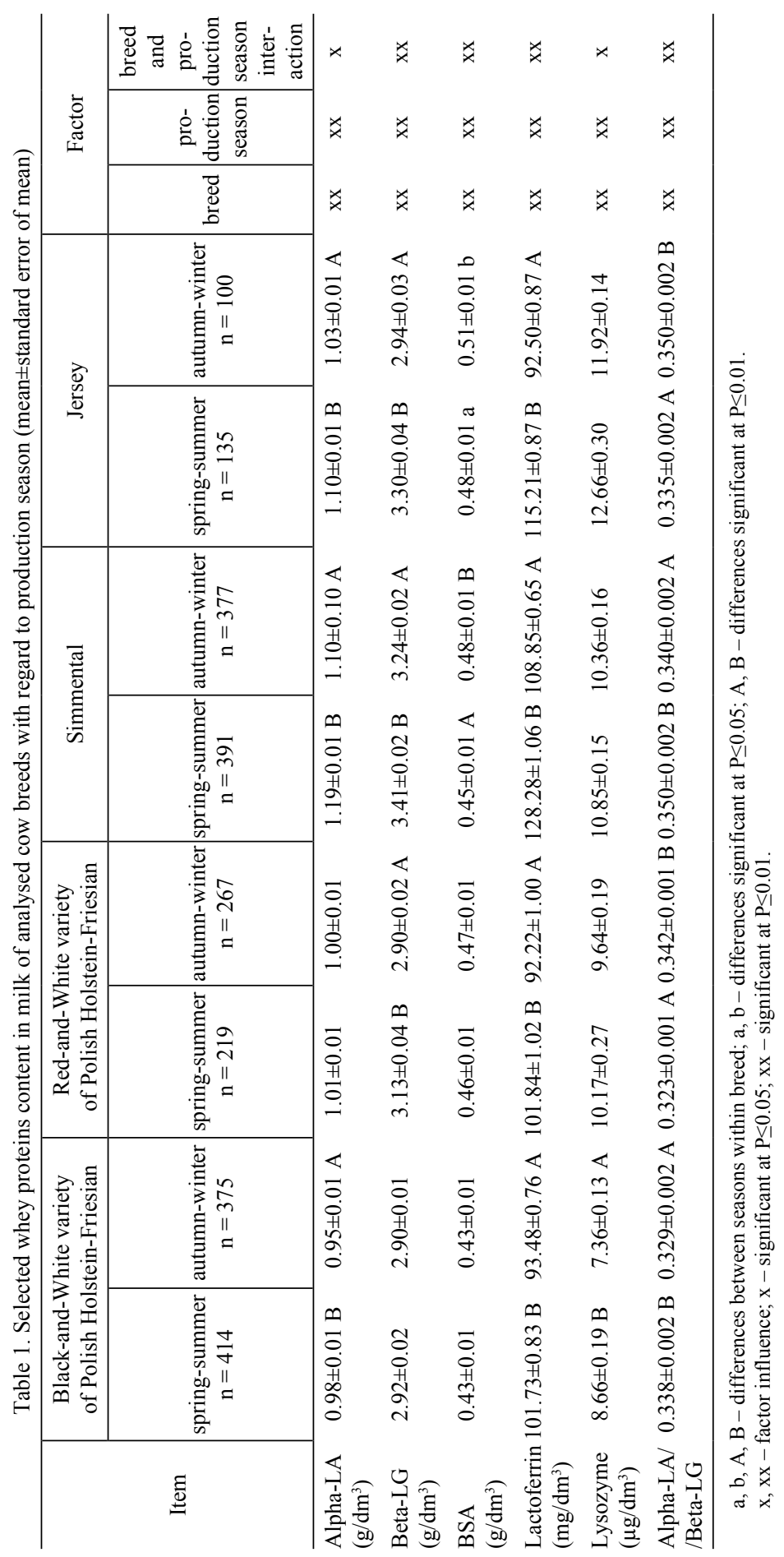




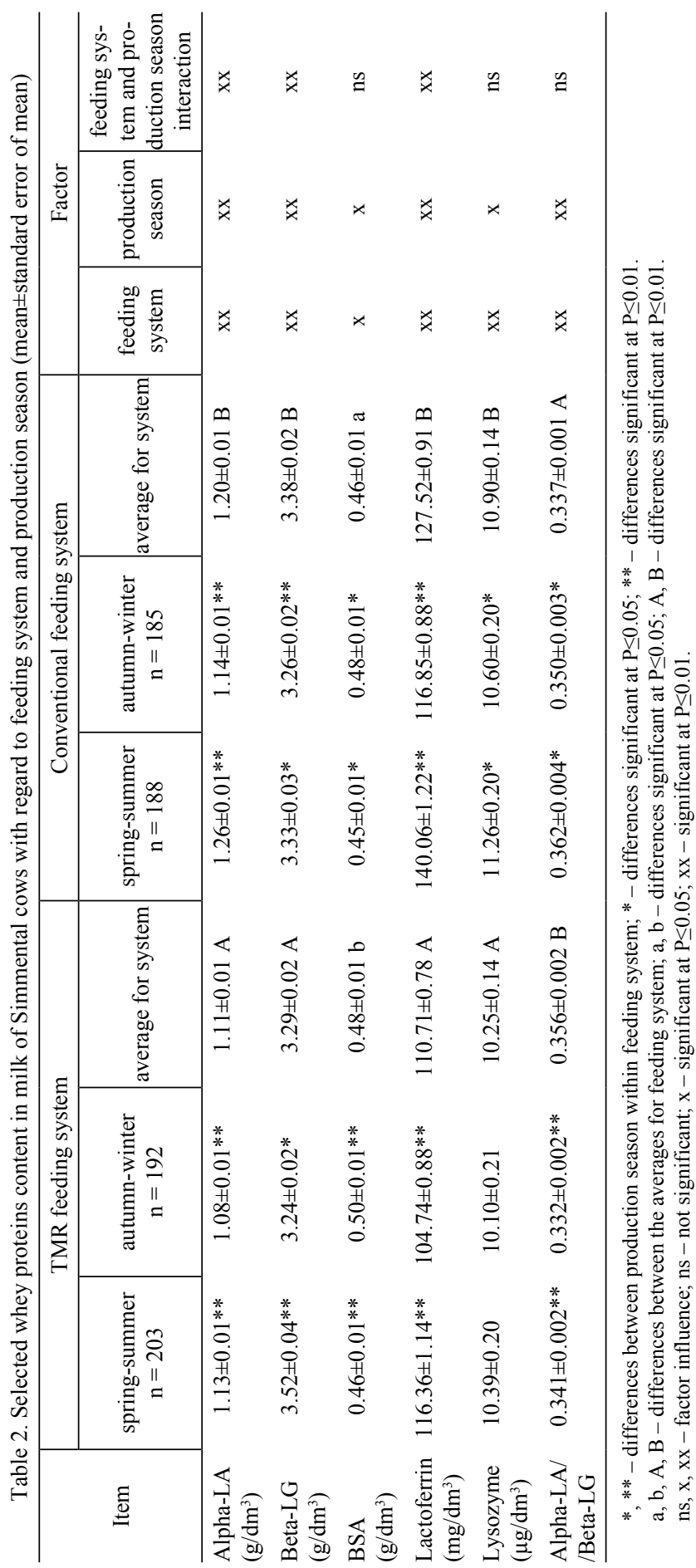




\section{Discussion}

The chemical composition of milk depends mainly on genetic and environmental factors, as well as their interactions. Nevertheless, it should be noted that some parameters are more sensitive to changes occurring in the environment, primarily taking into account a production system (Bilik and Łopuszańska-Rusek, 2010; Croissant et al., 2007).

Our results are consistent with those obtained by Wielgosz-Groth (2004), who found a significantly higher content of alpha-LA and beta-LG in the milk of Polish Holstein-Friesian cows from the spring-summer season, in comparison with the autumn-winter period. In other studies the authors showed that milk from local cow breeds, especially the Polish Red breed, is a more valuable source of functional whey proteins, especially in the summer season when animals grazed outdoors. The results obtained for two-way analysis of variance with interaction indicate, similarly to our study, a significant effect of breed on the content of all proteins analysed, i.e. alphaLA, beta-LG, lactoferrin and BSA. Nevertheless, the results do not confirm a significant $(\mathrm{P} \leq 0.05$ and $\mathrm{P} \leq 0.01)$ effect of breed and production season interaction on the content of these compounds (Król et al., 2010 b). The authors noted, however, slight differences between seasons in whey protein content in milk from Polish HolsteinFriesian that reached $0.05 \mathrm{~g} / \mathrm{dm}^{3}$ for alpha-LA, $0.06 \mathrm{~g} / \mathrm{dm}^{3}$ for beta-LG and $13.7 \mathrm{mg} /$ $\mathrm{dm}^{3}$ for lactoferrin in favour of the summer season. No significant seasonal changes in the content of bioactive components in milk were also confirmed by Reklewska et al. (2003), who analysed the milk of Black-and-White cows with at least $85 \%$ of Holstein-Friesian genes. Interestingly, Litwińczuk et al. (2011) showed that elevation of somatic cell count (SCC) produced a decrease in major albumins, i.e. alphaLA and beta-LG. SCC growth caused a significant rise in immunoactive proteins (lactoferrin and lysozyme) as well as bovine serum albumin (BSA). The interactions between breed and SCC for the BSA content have indicated varying susceptibility of the analysed cow breeds to the increase in somatic cell count.

The quality of milk obtained is determined mainly by feeding, which, however, is strongly associated with the production season (Barłowska et al., 2009; Bilik and Łopuszańska-Rusek, 2010; Croissant et al., 2007). Compared to our research, Król et al. (2008) found that the milk of Simmental cows kept on the pasture was characterized by a higher content of whey proteins, in comparison to the cows managed under TMR system. Significant differences $(\mathrm{P} \leq 0.01)$ were observed particularly in the concentration of beta-LG, which was about $0.34 \mathrm{~g} / \mathrm{dm}^{3}$ higher in the milk of cows grazing the pasture. Milk was also characterized by a higher content of alpha-LA (by $0.14 \mathrm{~g} / \mathrm{dm}^{3}$ ) and lactoferrin (by $27.9 \mathrm{mg} / \mathrm{dm}^{3}$ ). Moreover, these results are also supported by an investigation of Reklewska et al. (2003), who noted that the concentration of whey proteins in the milk from Polish Holstein-Friesian cows, depending on the feeding system, ranged from 1.11 to $1.37 \mathrm{~g} / \mathrm{dm}^{3}$ for alpha-LA and from 3.04 to $3.74 \mathrm{~g} / \mathrm{dm}^{3}$ for beta-LG. According to Mackle et al. (1999), a decrease in the main albumin content of milk occurred in the case of cows fed a limited amount of forage, compared to animals receiving additional concentrates. The authors stated that an increase in the amount of energy taken from the feed has an effect on the concentra- 
tion of whey proteins in milk. However, Turner et al. (2007) showed a significantly higher content of lactoferrin in milk of cows with unlimited access to pasture, in contrast to restricted grazed cows. On average, animals grazed ad libitum took daily twice as much as dry matter in the ration, which resulted in an increase in production of milk constituents. In another study, cows managed under the conventional system, in contrast to organic feeding, produced milk with a higher content of solids, including crude protein and casein (Bilik and Łopuszańska-Rusek, 2010).

In conclusion, it should be noted that evaluating the simultaneous effect of breed and production season on whey protein content showed significant interactions $(\mathrm{P} \leq 0.05$ and $\mathrm{P} \leq 0.01)$ for all analysed whey proteins. The milk of Simmental cows kept in the conventional system was characterized by a higher content of whey proteins (with the exception of BSA), in comparison to the cows managed under TMR system. Furthermore, for most of the analysed components, except for the content of BSA, lysozyme and alpha-LA/beta-LG ratio, the simultaneous effect of feeding system and production season was also found.

\section{References}

AOAC (2000). Official Methods of Analysis. Collection of Milk Laboratory Sample. AOAC Int., 925.20, Chapter 33, p. 4.

B arłowska J., Grodzi cki T., T opyła B., Litwińczuk Z. (2009). Physicochemical properties of milk fat from three breeds of cows during summer and winter. Arch. Tierz., Dummerstorf, 52, 4: 353-356.

B ilik K., Łopuszańska-R us e k M. (2010). Effect of organic and conventional feeding of Redand-White cows on productivity and milk composition. Ann. Anim. Sci., 10, 4: 441-458.

Croissant A.E., Washburn S.P., Dean L.L., Drake M.A. (2007). Chemical properties and consumer perception of fluid milk from conventional and pasture-based production systems. J. Dairy Sci., 90, 11: 4942-4953.

F arre 11 H.M., J i m e n e z - F 1 or e s R., B le c k G.T., B r ow n E.M. (2004). Nomenclature of the proteins of cows' milk. J. Dairy Sci., 87, 6: 1641-1675.

In d y k H.E. (2009). Development and application of an optical biosensor immunoassay for $\alpha$-lactalbumin in bovine milk. Int. Dairy J., 19: 36-42.

$\mathrm{K}$ on rad G., K lein s chmidt T. (2008). A new method for isolation of native $\alpha$-lactalbumin from sweet whey. Int. Dairy J., 18: 47-54.

Kró1 J., Litwińczuk Z., Litwińczuk A., Brodziak A. (2008). Content of protein and its fractions in milk of Simmental cows with regard to a rearing technology. Ann. Anim. Sci., 1: 57-61.

Król J., Litwińczuk Z., Brodziak A., B arłowska J. (2010 a). Lactoferrin, lysozyme and immunoglobulin $\mathrm{G}$ content in milk of four breeds of cows managed under intensive production system. Pol. J. Vet. Sci., 13, 2: 357-361.

Król J., Litwińczuk Z., Brodziak A., S awicka-Zugaj W. (2010 b). Bioactive protein content in milk from local breeds of cows included in the genetic resources conservation programme. Ann. Anim. Sci., 10, 3: 213-221.

Krzyżewski J., Strzałk owska N., Ryniewicz Z. (1997). Genetic and environmental factors affecting protein content in milk of cows (in Polish). Prz. Hod., 8: 8-9.

Litwińczuk Z., Król J., Brodziak A., B arłowska J. (2011). Changes of protein content and its fractions in bovine milk from different breeds subject to somatic cell count. J. Dairy Sci., 94, 2: 684-691.

Li u H.C., Chen W.L., Ma o S.J.T. (2007). Antioxidant nature of bovine milk $\alpha$-lactoglobulin. J. Dairy Sci., 90: 547-555. 
Mackle T.R., Bryant A.M., Petch S.F., Hill J.P., A uldist M.J. (1999). Variation in the composition of milk protein from pasture-fed dairy cows in the late lactation and the effect of grain and silage supplementation. New Zeal. J. Agr. Res., 42: 147-154.

Reklewska B., Bernatowicz E., Reklewski Z., Nałęcz-Tarwacka T., Kuczyńska B., Zdziarski K., Oprządek A. (2003). Content of biological active components in milk of cows depending on system and season of feeding (in Polish). Zesz. Nauk. Prz. Hod., 68, 1: 85-98.

Romero C., Perez-Andujar O., Jimenes S. (1996). Detection of cow's milk in ewe's or goat's milk by HPLC. Chromatographia, 42: 181-184.

T u rn er S.A., T ho m s o n N.A., A u l d i s t M.J. (2007). Variation of lactoferrin and lactoperoxidase in bovine milk and the impact of level of pasture intake. New Zeal. J. Agr. Res., 50: 33-40.

W a 1 k e r G.P., D un s h e a F.R., D o y l e P.T. (2004). Effects of nutrition and management on the production and composition of milk fat and protein: a review. Aust. J. Agr. Res., 55, 10: 1009-1028.

W i e l g o s z - G r o t h Z. (2004). Effects of Black and White cows' breed utility improving in the region of north-eastern Poland (in Polish). Dissertations and Monographs, UWM. Olsztyn.

Accepted for printing 27 II 2012

\section{ANETA BRODZIAK, JOANNA BARŁOWSKA, JOLANTA KRÓL, ZYGMUNT LITWIŃCZUK}

\section{Wpływ rasy i systemu żywienia krów na zawartość wybranych białek serwatkowych mleka w okresie wiosenno-letnim i jesienno-zimowym}

\section{STRESZCZENIE}

Celem pracy było określenie wpływu rasy i systemu żywienia krów na stężenie wybranych białek serwatkowych w mleku pozyskiwanym w okresie wiosenno-letnim i jesienno-zimowym. Badaniami objęto 2278 próbek mleka pobranych od krów rasy polskiej holsztyńsko-fryzyjskiej odmiany czarnoi czerwono-białej, Jersey oraz simentalskiej. W każdej próbce oznaczono zawartość alfa-laktoalbuminy, beta-laktoglobuliny, laktoferyny, krowiej albuminy serum i lizozymu, metodą RP-HPLC. Oceniając równoczesny wpływ rasy i sezonu produkcji na zawartość białek serwatkowych wykazano istotne interakcje dla wszystkich analizowanych białek serwatkowych. Mleko krów simentalskich utrzymywanych systemem tradycyjnym wyróżniało się wyższą zawartością białek serwatkowych (oprócz BSA) w porównaniu do żywionych systemem TMR. Dla większości analizowanych składników, z wyjątkiem zawartości BSA, lizozymu oraz stosunku alfa-laktoalbuminy do beta-laktoglobuliny, zanotowano również jednoczesny wpływ systemu żywienia i sezonu produkcji. 